
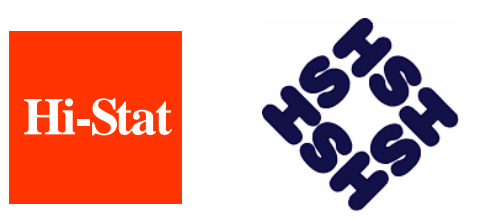

Discussion Paper Series

No.55

The Evolution of Japan's Aggressive Legalism

Ichiro Araki

December 2004

Hitotsubashi University Research Unit for Statistical Analysis in Social Sciences A 21st-Century COE Program

Institute of Economic Research Hitotsubashi University Kunitachi, Tokyo, 186-8603 Japan http://hi-stat.ier.hit-u.ac.jp/ 


\section{The Evolution of Japan's Aggressive Legalism}

\section{Ichiro Araki ${ }^{l}$}

\section{INTRODUCTION}

Japan's recent trade policy is sometimes characterized as "aggressive legalism" in the sense that it aggressively utilizes the multilateral trade rules embodied in the Marrakesh Agreement Establishing the World Trade Organization (WTO Agreement) in dealing with disputes with its trade partners. It is also explained that this policy is a marked departure from Japan's past practice of favoring bilateral, non-legal settlement of trade disputes. ${ }^{2}$ This paper examines the evolution of Japan's aggressive legalism. Section 2 analyzes the current state-of-play of dispute settlement in the WTO and Japan's relative position in comparison with other WTO members. Section 3 discusses various factors involved in Japan's policy toward the WTO dispute settlement system and the implications of Japan's recent enthusiasm for regional trade agreements. Section 4 discusses the possibility of a formal national complaint mechanism similar to Section 301 of the U.S. Trade Act of 1974. Section 5 concludes.

\section{JAPAN AND THE WTO DISPUTE SETTLEMENT MECHANISM}

Amongst the members of the WTO, Japan has had fairly frequent recourse to the dispute settlement mechanism under the Dispute Settlement Understanding (DSU). According to a statistical overview by the WTO Secretariat dated 14 June $2004^{3}$, out of the current 147 members of the WTO, 47 countries and customs territories have been involved in the dispute settlement

\footnotetext{
${ }^{1}$ ICHIRO ARAKI is fromYokohama National University. The author is deeply indebted to Tsuyoshi Kawase, Faculty of Law, Osaka University for his substantive contribution to this work and co-authorship of the initial draft of the paper. Thanks are also due to Dukgeun Ahn, KDI School, Korea, who provided helpful comments to the original manuscript.

${ }^{2}$ Pekkanen (2001), pp. 707-8.

${ }^{3}$ WTO (2004).
} 
process either as a complainant or a respondent. As shown in Table 1, in terms of the number of cases involved, Japan ranks seventh as a complaining party and fifth as a responding party. While not reaching the level of the two giants in the WTO system-the United States and the European Communities (EC), Japan's involvement in the dispute settlement system appears to be moderately active, commensurate with its economic and political power in the world. ${ }^{4}$

However, trade officials at the Ministry of Economy, Trade and Industry (METI) do not seem to be content with the status quo. Based on essentially the same statistical analysis, the 2004 edition of the METI's Fukosei boeki hokokusho ("Unfair Trade Policies Report") ${ }^{5}$ laments the existence of a "significant gap" between the performance of the United States and the EC on the one hand and that of Japan on the other "regarding the active use of international economic rules toward securing compliance with WTO obligations". 6 The report emphasizes the importance of improving Japan's initiatives toward securing its trading partners' compliance with the existing international trade rules, based on the recognition that such initiatives are inadequate at present.

This is not a statement that is expected from officials of a country that has embraced the strategy of aggressive legalism in the WTO. According to Pekkanen (2001, p732), who coined this term to describe Japan's recent trade strategy, aggressive legalism can be defined as "active use of the legal rules in the treaties and agreements overseen by the WTO to stake out positions,

\footnotetext{
4 Table 1 is a simple tallying of cases. In order to grasp a more accurate picture of Japan's state-of-play in the WTO dispute settlement process, a deeper analysis including the chronological trend may be necessary. Indeed, Leitner and Lester (2004) have made such an analysis for a period between 1995 and 2003, but their results are consistent with the findings above. See also Iida (2004).

${ }^{5}$ See note 24 below and the accompanying text.

${ }^{6}$ METI (2004), p.351. The translation is the author's. The English version of the 2004 report is available from the METI Website (http://www.meti.go.jp/english/report/index.html), but the translation of the relevant passage is omitted, perhaps because its intended audience is the Japanese citizens and companies.
} 
to advance and rebut claims, and to embroil all concerned in an intricate legal game.”

A closer examination of the cases involving Japan reveals some of the reasons behind this critical self-appraisal by the Japanese trade officials. Table 2 shows the cases in which Japan has been the complaining party. There have been ten distinct cases (counting the two complaints in the Indonesia Auto case as one), out of which eight went to the panel/Appellate Body stage. The following is a brief overview of these eight cases.

\section{a. Indonesia - Certain Measures Affecting the Automobile Industry (WT/DS55 and WT/DS64)}

This was a complaint regarding the "National Car Program" announced by the Indonesian Government in February 1996. While Japan had a substantive, as well as systemic, interest in this case as the major exporter of automobiles and auto parts to the Indonesian market, the situation was hardly unique to Japan. Major automobile exporters to Indonesia, i.e., Japan, EC and the United States, coordinated their positions before filing formal complaints with the WTO. Indeed, the first complaint regarding this measure was filed by the EC, with the request for consultations dated 3 October 1997 (WT/DS54/1). Japan's request for consultations followed on the next day (WT/DS55/1). The U.S. request was dated 8 October 1997 (WT/DS59/1). Japan filed the second request for consultations on 29 November 1997 (WT/DS64/1), but this was due to technical reasons. Thus, the complaints by the EC, Japan and the United States were filed almost simultaneously and as a result, a single panel was established to hear the three complaints.

What is noteworthy about the sequence of these events is that Japan was not the first WTO member to seek adjudication by the dispute settlement mechanism in this case. Rather, it opted for coordinating its action with the EC and the United States, and waited until the EC filed 
its complaint. ${ }^{7}$ Japan's involvement in the panel process was also well-coordinated with the two other co-complainants. The panel found that Indonesia was in violation of the rules of the General Agreement on Tariffs and Trade (GATT), inter alia, on most-favored-nation treatment and tariff bindings. Indonesia did not appeal the case and the panel report was adopted on 23 July 1998. Because of the Asian economic crisis of 1997-1998 and the collapse of the Suharto regime, Indonesia had to abandon its national car program. Thus, the complaining parties did not face the issue of implementation of the panel's recommendations.

\section{b. United States - Measure Affecting Government Procurement (WT/DS95)}

This complaint was about a Massachusetts state law enacted on 25 June 1996, which provided that public authorities of the Commonwealth of Massachusetts were not allowed to procure goods or services from any persons who did business with Burma (Myanmar). Clearly, this was an EC-led complaint. The EC alleged that this legislation was violating the rules of the Agreement on Government Procurement (GPA) and requested consultations with the United States on 20 June 1997 (WT/DS88/1). Japan filed its own complaint based on similar allegations on 18 July 1997 (WT/DS95/1). In October 1998, a single panel was established to hear the two complaints. While the panel hearing was in progress, a domestic lawsuit was initiated in the United States regarding the constitutionality of this law. Ultimately, in a June 2000 decision, the U.S. Supreme Court found the Massachusetts law to be unconstitutional. ${ }^{8}$ In view of these developments, on 10 February 1999, the complainants requested the panel to suspend the panel proceedings. Pursuant to Article 12.12 of the DSU, the authority for establishment of the panel lapsed as of 11 February 2000. However, as the Massachusetts law was declared null and void by

\footnotetext{
7 The Daily Yomiuri (October 3, 1996), based on a Kyodo News story, reported that then Chief Cabinet Secretary Seiroku Kajiyama said "Japan, the United States and European countries are likely to unite to try to persuade Indonesia to drop its policy, which they say discriminates against industrialized countries."

8 Crosby v. National Foreign Trade Council, 530 U.S. 363 (2000).
} 
the U.S. judiciary, the complainants were satisfied with the outcome of this case.

\section{c. Canada - Certain Measures Affecting the Automotive Industry (WT/DS139)}

This complaint was about measures taken under Canadian legislation implementing an automotive products agreement ("Auto Pact") between the United States and Canada. Under this scheme, only a limited number of motor vehicle manufacturers were eligible to import vehicles into Canada duty free and to distribute the motor vehicles in Canada at the wholesale and retail distribution levels. Japan contended that this duty-free treatment is contingent on two requirements: (1) a Canadian value-added content requirement that applied to both goods and services; and (2) a manufacturing and sales requirement. Japan alleged that these measures were inconsistent with Canada's obligations under the GATT as well as those under the General Agreement on Trade in Services (GATS). On 3 July 1998, Japan requested consultations with Canada (WT/DS139/1). On 17 August 1998, the EC requested consultations with Canada in respect of the same measures raised by Japan (WT/DS142/1). In February 1999, a single panel was established to hear the two complaints, and the panel issued its report finding in favor of the complaining parties in February 2000. Canada appealed the case, and the Appellate Body largely upheld the panel's findings and conclusions. The Appellate Body report and the panel report as modified by the Appellate Body report were adopted on 19 June 2000. Since Canada subsequently abolished the measures in question, the implementation of the panel's recommendations did not become a major issue for the complaining parties.

In many respects, this case is similar to the Indonesia Auto case described above. However, unlike the Indonesia Auto case, it was Japan that initiated the complaint. This was probably because of the pressure from the Japanese auto companies invested in Canada that were not benefiting from the Auto Pact scheme (Toyota and Honda in particular). Despite one Japanese company (Suzuki) being a beneficiary of the Auto Pact scheme, the Japanese Government decided to go ahead with this case. Since the interests of the Japanese car manufacturers were split, the Ministry of International Trade and Industry (MITI) was not able to gain full support from the 
industry association, the Japan Automobile Manufacturers Association. Perhaps because of this weak support, MITI needed a partner in the WTO dispute settlement process. Like the preceding Indonesia Auto case, it formed an alliance with the EC. In the panel and Appellate Body process, the positions of the two complainants were well-coordinated and Japan certainly benefited from the eloquence of the veteran EC lawyers in oral hearings.

As Canada implemented the panel/Appellate Body recommendations by abolishing the domestic measures that implemented the Auto Pact relatively smoothly within the reasonable period of time, the complaining parties did not face a serious issue of compliance.

\section{d. United States - Anti-Dumping Act of $1916($ WT/DS162)}

This complaint was about the U.S. legislation commonly called The Anti-Dumping Act of 1916. The Act stipulated that the importation or sale of imported goods within the U.S. market in certain circumstances was unlawful, constituting a criminal offence and inviting civil liability. On 10 February 1999, Japan requested consultations with the United States regarding this legislation (WT/DS162/1). Japan alleged that judicial decisions under the 1916 Act were made without the procedural safeguards provided for in the Anti-Dumping Agreement and that as such the 1916 Act was inconsistent with Articles III, VI and XI of GATT and the Anti-Dumping Agreement. This complaint was essentially the same as the earlier case initiated by the EC on 9 June 1998 (WT/DS136/1). By the time of Japan's request for consultations, a panel had been established to hear the EC's complaints. Japan participated in the earlier case as an interested third party, but decided to initiate its own action because a court action was brought under the 1916 Act against affiliates of Japanese companies by a steel producer called Wheeling Pittsburgh in November 1998. (The earlier EC action was also motivated by a steel-related lawsuit known as the Geneva Steel case.)

Because of the timing of Japan's request, two separate panels were established to hear the complaints by the EC and Japan (WT/DS136 and WT/DS162). However, the panelists were the same individuals and they acted as if they were a single panel hearing a joint complaint by the 
EC and Japan. The panel reports essentially accepted the claims by the EC and Japan and found that the 1916 Act was inconsistent with the U.S. obligations under the Anti-Dumping Agreement and suggested that the United States could bring the measure into conformity with its WTO obligations by repealing the 1916 Act. The United States appealed to the Appellate Body in respect of the panel reports in WT/DS136 and WT/DS162. In a joint report circulated on 28 May 2000, the Appellate Body upheld all of the findings and conclusions of the panel that were appealed. The panel and Appellate Body reports were adopted on 26 September 2000. The 1916 Act is not yet repealed, and a compliance dispute is still ongoing between the EC and Japan on the one hand and the United States on the other.

On 7 January 2002, on the grounds that that the United States had failed to bring its measures into conformity within the reasonable period of time, the EC and Japan requested authorization to retaliate against the United States pursuant to Article 22.2 of the DSU. Both the EC and Japan proposed that the retaliation takes the form of an equivalent legislation to the Anti-Dumping Act of 1916 against imports from the United States. The United States objected to the levels of suspension of obligations proposed by the EC and Japan and requested the DSB to refer the matter to arbitration, in accordance with Article 22.6 of the DSU. The EC and Japan agreed to suspend the arbitration process in view of the legislative proposals in the U.S. Congress. However, since no legislation had been adopted to repeal the 1916 Act and to terminate the cases pending before the U.S. courts, on 19 September 2003 the EC requested the arbitrators to reactivate the arbitration proceeding regarding their case (WT/DS136).

On 24 February 2004, the decision by the arbitrators was circulated to WTO members. The arbitrators decided to set a number of parameters ((1) damages paid by EC companies as a result of judgments under the 1916 Act and (2) amount of any settlement reached between an EC company and a U.S. complainant pursuant to a 1916 Act complaint) with which the EC will have to comply when calculating by itself the amount of countermeasures it plans to impose, rather than setting a fixed value of trade as the maximum limit of retaliation. Japan has not yet requested the resumption of the arbitration process for their case (WT/DS162). Clearly, this has 
been an EC-led case from the early phase to the implementation/compliance phase.

\section{e. United States - Anti-Dumping Measures on Certain Hot-Rolled Steel Products from Japan (WT/DS184)}

On 18 November 1999, Japan requested consultations with the United States in respect of the preliminary and final determinations of the U.S. Department of Commerce and the U.S. International Trade Commission on the anti-dumping investigation of Certain Hot Rolled Steel Products from Japan issued in November 1998, February 1999, April 1999 and June 1999. Japan alleged that these determinations were erroneous and based on deficient procedures under the U.S. Tariff Act of 1930 and related regulations. The Japanese complaint also concerned certain provisions of the Tariff Act of 1930 and related regulations. Japan claimed violations of Articles VI and X of the GATT and several provisions of the Anti-Dumping Agreement.

On 11 February 2000, Japan requested the establishment of a panel, which took place on 20 March 2000. In a report circulated on 28 February 2001, the panel largely accepted Japan's claims and concluded that the United States acted inconsistently with its obligations under the Anti-Dumping Agreement.

On 25 April 2001, the United States notified its decision to appeal to the Appellate Body certain issues of law covered in the panel report and certain legal interpretations developed by the panel. The Appellate Body circulated its report on 24 July 2001. The Appellate Body upheld most of the panel's findings

On 23 August 2001, the Appellate Body report and the panel report as modified by the Appellate Body report were adopted. While the United States took some actions to comply with the panel/Appellate Body recommendations in respect of recalculation of dumping margins, the United States has yet to implement the necessary legislative changes to bring the measure fully into conformity with its WTO obligations. The reasonable period of time for implementation of the panel/Appellate Body recommendations determined by arbitration would have expired on 23 November 2002. However, the United States requested the extension of this period several times, citing the difficulties in the legislative process, and Japan so far has agreed to it. Unlike the 
Anti-Dumping Act of 1916 case, Japan has not requested the authorization for retaliation.

\section{f. United States - Continued Dumping and Subsidy Offset Act of 2000 (WT/DS217)}

This was a joint complaint by Australia, Brazil, Chile, European Communities, India, Indonesia, Japan, Korea and Thailand (WT/DS217), and Canada and Mexico (WT/DS234). On 21 December 2000 and 21 May 2001 respectively, the complainants requested consultations with the United States concerning the amendment to the Tariff Act of 1930 signed on 28 October 2000 with the title of "Continued Dumping and Subsidy Offset Act of 2000" usually referred to as "the Byrd Amendment". The complainants alleged that the Byrd Amendment was inconsistent with the obligations of the United States under several provisions of the GATT, the Anti-Dumping Agreement, the Agreement on Subsidies and Countervailing Measures (SCM Agreement), and the WTO Agreement.

On 23 August 2001, a panel was established in respect of WT/DS217 and on 10 September 2001, another panel was established in respect of WT/DS234, with the understanding that the former would also examine the claims in the latter. In a report circulated on 16 September 2002, the panel concluded that the Byrd Amendment was inconsistent with Articles 5.4, 18.1 and 18.4 of the Anti-Dumping Agreement, Articles 11.4, 32.1 and 32.5 of the SCM Agreement, Articles VI:2 and VI:3 of the GATT 1994, and Article XVI:4 of the WTO Agreement. The United States appealed, but in a report circulated on 16 January 2003, the Appellate Body largely upheld the findings and conclusions of the panel. The Appellate Body report and the panel report as modified by the Appellate Body were adopted on 27 January 2003. As the United States has not repealed the Byrd Amendment, the implementation dispute is still ongoing between the complaining parties and the United States. On 15 January 2004, on the grounds that the United States had failed to implement the DSB recommendations and rulings within the reasonable period of time, Brazil, Chile, the EC, India, Japan, Korea, Canada and Mexico requested the DSB authorization to retaliate against the United States pursuant to Article 22.2 of the DSU. On 23 January 2004, the United States requested, in accordance with Article 
22.6 of the DSU, that the matter be referred to arbitration, since the United States objected to the level of suspension of concessions proposed by the foregoing parties. At its meeting on 26 January 2004, the DSB decided to refer the matter to arbitration.

\section{g. United States - Sunset Review of Anti-Dumping Duties on Corrosion-Resistant Carbon Steel Flat Products from Japan (WT/DS244)}

On 30 January 2002, Japan requested consultations with the United States in respect of the final determinations of both the U.S. Department of Commerce (DOC) and the U.S. International Trade Commission in the full sunset review of the anti-dumping duties imposed on imports of corrosion-resistant carbon steel flat products from Japan. These determinations were issued on 2 August 2000 and 21 November 2000, respectively. Japan claimed that these determinations were erroneous and based on deficient rulings, procedures and provisions pertaining to the United States Tariff Act of 1930, as amended and related regulations. Japan further claimed that the procedures and provisions of the Act and related regulations as well as the above determinations were inconsistent with, inter alia, Articles VI and X of GATT 1994; Articles 2, 3, 5, 6 (including Annex II), 11, 12, and 18.4 of the Anti-Dumping Agreement; and Article XVI:4 of the WTO Agreement.

On 22 May 2002, a panel was established. In a report circulated on 14 August 2003, the panel rejected all of Japan's claims challenging various aspects of the U.S. laws and regulations regarding the conduct of "sunset" reviews of anti-dumping duties under U.S. law. The panel found, inter alia, that the obligations pertaining to evidentiary standards for self-initiation and de minimis standards in investigations do not apply to sunset reviews. The panel also rejected Japan's argument that the U.S. Sunset Policy Bulletin - which, by its own terms, provides guidance on methodological or analytical issues not explicitly addressed by the U.S. statute and regulations - was a mandatory instrument that could be challenged as such in WTO dispute settlement. Rather, the Panel found that the Bulletin may be challenged only in respect of its application by the DOC in a particular case. The panel further found that the DOC's 
determination of likelihood of continuation or recurrence of dumping in this particular case was not WTO-inconsistent. Accordingly, the panel made no recommendation to the United States.

Japan appealed from this finding. On 15 December 2003, the report of the Appellate Body was circulated to Members. The Appellate Body upheld three findings, but reversed four of the Panel's legal findings. The Appellate Body found, contrary to the panel, that the Bulletin could be challenged in WTO dispute settlement. However, the Appellate Body did not find any of the provisions of the Bulletin inconsistent with the Anti-Dumping Agreement or the WTO Agreement. Although its analysis of Japan's claims differed from that of the Panel in important respects, the Appellate Body did not make any finding that the United States had acted inconsistently with its obligations under the Anti-Dumping Agreement or the WTO Agreement. The Appellate Body report and the panel report as modified by the Appellate Body report were adopted on 9 January 2004. Due to the nature of the findings above, no implementation/compliance issue was involved regarding this case.

\section{h. United States - Definitive Safeguard Measures on Imports of Certain Steel Products (WT/DS249)}

On 20 March 2002, Japan requested consultations with the United States with regard to the definitive safeguard measures imposed by the United States on the imports of certain steel products, alleging violations of Articles 2.1, 2.2, 3.1, 3.2, 4.1, 4.2, 5.1, 7.1, 7.4. 8.1, 12.1, 12.2, 12.3 of the Agreement on Safeguards and Articles I:1, II, X:3, XIII and XIX:2 of the GATT. This was part of the massive complaints by the EC (WT/DS248), Japan (WT/DS249), Korea (WT/DS251), China (WT/DS252), Switzerland (WT/DS253), Norway (WT/DS254), New Zealand (WT/DS258) and Brazil (WT/DS259) regarding the controversial U.S. safeguard measures on certain steel products.

A single panel was established to hear these complaints in several meetings of the Dispute Settlement Body (DSB) held between 3 June 2002 and 29 July 2002. In a report circulated on 11 July 2003, the panel found that the U.S. safeguard measures at issue were 
inconsistent with at least one of the following WTO pre-requisites for the imposition of a safeguard measure: lack of demonstration of (i) unforeseen developments; (ii) increased imports; (iii) causation; and (iv) parallelism. The panel thus requested the United States to bring the relevant safeguard measures into conformity with its obligations under the Agreement on Safeguards and the GATT.

The United States appealed this finding. In a report circulated on 10 November 2003, the Appellate Body upheld the Panel's ultimate conclusions that each of the ten safeguard measures at issue in this dispute was inconsistent with the U.S. obligations under Article XIX:1(a) of the GATT and the Agreement on Safeguards. The Appellate Body reversed the Panel's findings that the United States failed to provide a reasoned and adequate explanation on "increased imports" and on the existence of a "causal link" between increased imports and serious injury for two of the ten safeguard measures. Ultimately, however, even these measures were found to be inconsistent with the WTO Agreement on other grounds. At its meeting on 10 December 2003, the DSB adopted the Appellate Body report and the panel report as modified by the Appellate Body report. Immediately thereafter, the United States withdrew the safeguard action at issue. One factor behind this quick move by the United States was the existence of "rebalancing" provisions under GATT Article XIX and the Agreement on Safeguards, where the importing countries were able to impose retaliatory measures immediately without seeking authorization from the DSB. The EC and Japan, among others, threatened that in the absence of immediate U.S. compliance with the panel/Appellate Body recommendation, they would impose retaliatory tariffs on U.S. products.

\section{i. Overview of Cases}

The discussion above reveals that in six out of the eight cases that reached the panel/appellate stage, Japan was either a co-complainant of the EC or a part of the joint complaints led by the EC. Only in the Hot-rolled Steel case (WT/DS184) and the Sunset Review case (WT/DS244), did Japan act alone. In a broader context, even the Sunset Review case could 
be regarded as part of the joint efforts led by the EC (WT/DS213), and followed by Argentina (WT/DS268) and Mexico (WT/DS282) in challenging the U.S. practice regarding the sunset review of anti-dumping and countervailing duties.

Another characteristic of Japan's WTO dispute settlement strategy is geographic concentration of respondents. As shown in Table 1, the United States has been the prime target of Japan's complaints (7 out of 11). In the eight cases reviewed above, the United States was the respondent in six cases. The EC has never been the target of Japan's complaints. Japan seldom challenges measures taken in developing countries. The automobile cases against Brazil (WT/DS51) and Indonesia (WT/DS55 and WT/DS64) were earlier exceptions to this trend, but recently Japan does not seem to have focused its attention on developing countries' trade practices or measures. It should also be noted that the challenges against Brazil and Indonesia were part of the joint action with the United States and the EC.

Also noteworthy is the high ratio of cases reaching the panel/appellate stage ( 8 cases out of 10 distinct matters). While some WTO members, particularly the United States and the EC, occasionally have recourse to the WTO dispute settlement mechanism to induce a bilateral settlement, this does not seem to have been the policy of Japan. Japan seems to have been highly selective in filing cases, carefully avoiding frivolous claims and focusing on winnable cases, although miscalculations are still inevitable as in the defeat in the Sunset Review case. Once Japan files a formal complaint with the WTO, it is determined to pursue the case all the way to the end. The primary aim is to seek third-party adjudication and not to extract bilateral concessions. This could be the reason for the relatively small number of complaints filed by Japan, in contrast to the United States and the EC.

The picture that emerges from the above analysis is not necessarily an aggressive user of the WTO dispute settlement mechanism. Rather, it is a country that resorts to surgical strikes on selected targets (usually the United States) under a powerful cover of the EC.

A similar analysis could be attempted regarding cases where Japan has been the 
responding party. ${ }^{9}$ However, Japan's reaction in those cases naturally tends to be reactive and it is difficult to find a discernible pattern. Probably it is not very useful in the analysis of Japan's aggressive legalism. Ahn (2003), however, suggests that Japan's victory in Japan - Measures Affecting Consumer Photographic Film and Paper (WT/DS44) may have had a profound impact on the thinking of the Japanese trade officials in pursing aggressive legalism. According to Ahn (p. 14), "Despite strenuous efforts by the United States to vindicate its claims, the panel ruled that the United States failed to demonstrate that, under GATT Article XXIII:1(b), the distribution 'measures' nullify or impair benefits accruing to the United States. This ultimate legal victory for Japan under the WTO dispute settlement system, after initiated by positive determination under the Section 301 proceeding, substantially strengthened the Japanese government's position concerning its domestic trade policies. Typically, Japan has been vulnerable to blame for its convoluted non-tariff barriers. But, after this case, the Japanese government has become much more stubborn in accepting its trading partners' claims concerning unjustified or unreasonable non-tariff barriers, at least administered by the government." While the author agrees with Ahn on the significance of the Film case on the thinking of Japanese trade officials, particularly in boosting its confidence in the multilateral trading system, it is questionable whether they have become more "stubborn" in accepting the claims of non-tariff barriers by its trading partners. Further study will be needed to answer the point raised by Ahn.

One other noteworthy characteristic regarding cases involving Japan as respondent is that complaints against Japan were frequent until around October 1998. Since then, only one Japanese measure (Apples, WT/DS245) has been challenged. Ahn (2003) suggests that this may have to do with the changing nature of Japan's trade barriers. He argues (p. 14): “[A]fter somewhat intensive probing by other WTO Members in the early WTO years, systemic or legal inconsistency of domestic policy measures or legal systems were mostly addressed and modified to comply with the WTO disciplines. There remain, therefore, few systemic problems to be

\footnotetext{
9 See Table 3.
} 
addressed at least in terms of the current WTO disciplines." On the other hand, it is known that across the WTO membership in general there was a large increase in the number of complaints filed over the first three years of the WTO, with a decrease over the next couple of years. Over the last few years, as Leitner and Lester (2000, p. 170) note, the number of complaints has remained fairly steady. The number of cases against Japan may be simply following this general trend.

The uniqueness of Japan's attitude toward the WTO dispute settlement is highlighted by a comparison with Korea. Ahn (2003, p. 15) has observed that "Under the WTO system, the Korean government changed a dispute aversion attitude and has become considerably more active in asserting its rights through the dispute settlement mechanism." As shown in Table 1, in terms of the number of cases involved, Japan and Korea are at about the same level. Korea also appears to be selective in trying to choose winnable cases. Like Japan, Korea has filed 11 complaints in 10 distinct matters, out of which four cases are still pending. Among the remaining seven completed cases, five reached the panel/appellate stage. Even among the four pending cases, panel composition is complete in two cases. This makes the ratio of cases reaching the panel stage as 7 out of 10 (which is comparable to the figure for Japan, 8 out of 10). However, the similarities end there. Unlike Japan, Korea usually files complaints alone, without co-complaining partners. The only exceptions are the Byrd Amendment case (WT/DS217) and the Steel Safeguards case (WT/DS251) discussed above. Furthermore, Korea has not shied away from challenging trade policies and practices of the EC. It has already filed three separate complaints (WT/DS299, WT/DS301 and WT/DS307) against the EC in two distinct matters (countervailing duties on semiconductors and shipping subsidies). Korea has even challenged an anti-dumping measure by the Philippines (WT/DS215). Geographical concentration of targets is not a Korean characteristic.

All in all, Korea seems to be more aggressive than Japan in dealing with WTO disputes, let alone those countries with more complaints than Japan - Canada, Brazil, India and Mexico as shown in Table 1. It is no surprise that METI trade officials seem to think that Japan's 
aggressiveness has more room for improvement.

\section{NOT-SO-AGGRESSIVE LEGALISM?}

Does the analysis above mean that Pekkanen (2001, p. 732) was wrong when she concluded, "Japan's aggressive legalism is here to stay"? The author does not believe so.

Japan's aggressive legalism must be understood in the historical context. For a long period of time, Japan was viewed in the GATT as a supporter of a less legalistic approach to dispute settlement, preferring a system of relying on negotiation and compromise instead of adjudication. ${ }^{10}$ This was probably because trade policymakers of the day were preoccupied with the notion of "those who live in glass houses should not throw stones." The reluctance may well have stemmed from fears of exposing Japan's many visible trade barriers and restrictive practices to legal scrutiny. This type of thinking may have dominated the minds of the policymakers in the mid-1980s. As I note in Araki (2004), when this is combined with the relative inexperience with the art of legal presentation and language barriers, it is not surprising that Japanese trade officials of the day preferred bilateral negotiations to the formal dispute settlement mechanism.

A turning point arrived in the Parts and Components case, ${ }^{11}$ the very first GATT complaint initiated by Japan that reached the panel stage. The road to this case was paved by a series of losses that Japan suffered in GATT panel cases in the late 1980s. First, in a panel report submitted to the parties in September 1987, the Japanese liquor tax was found to be in violation of GATT Article III:2. ${ }^{12}$ Another panel report submitted in October 1987 found the Japanese

\footnotetext{
10 Davey (2002, p. 129).

${ }^{11}$ EEC - Regulation on Imports of Parts and Components, Report by the Panel adopted on 16 May 1990 (L/6657 BISD 37S/132).

12 Japan - Customs Duties, Taxes and Labelling Practices on Imported Wines and Alcoholic Beverages, Report of the Panel adopted on 10 November 1987 (L/6216 - BISD 34S/83).
} 
import restrictions on certain agricultural products to be in violation of GATT Article XI:1. ${ }^{13}$ Finally, a panel report submitted in March 1988 found that Japan's export restraint under the Japan-US Semiconductor Agreement was a violation of GATT Article XI:1. ${ }^{14}$ Under such circumstances, Japanese government officials apparently felt that Japan too should assert its rights when it had a good case under the GATT. ${ }^{15}$

There were two other factors that helped Japan in challenging the EC in the Parts and Components case. Japanese trade officials had become accustomed to the GATT panel procedures through preparing defenses in the cases brought against Japan. Also, by this time, complaints by other contracting parties were filed with the GATT in a more businesslike manner, decreasing the level of psychological barriers for Japanese trade officials.

Once victory in the Parts and Components case was confirmed, the trend towards aggressive legalism became irreversible. ${ }^{16}$ MITI started publishing its annual report on the GATT consistency of Japan's major trading partners in $1992 .{ }^{17}$ The report, which in Japanese

${ }^{13}$ Japan - Restrictions on Imports of Certain Agricultural Products, Report of the Panel adopted on 2 February 1988 (L/6253 - BISD 35S/163).

${ }^{14}$ Japan-Trade in Semi-Conductors, Report of the Panel adopted on 4 May 1988 (L/6309 - BISD 35S/116). The panel concluded that the Japanese measure to restrict "dumped" exports of semiconductors to the United States and third markets - a typical "gray area" measures limiting the export volumes "voluntarily" through administrative guidance - was indeed a violation of GATT Article XI:1.

15 Iwasasa (2000, p. 477).

16 According to a memoir by a former MITI vice minister for international affairs, the exact timing of this policy change can be pinpointed to a specific date, 10 April 1991, when the MITI officially announced the policy of upholding and utilizing international economic rules in a briefing paper submitted to the Administrative Reform Council. See Hatakeyama (1996, p. 287).

${ }^{17}$ The report has been published annually ever since. The report is authored by a subcommittee of experts in the Industrial Structure Council, an advisory organ to the METI (MITI until 2001) Minister. However, since the secretariat function of the subcommittee is performed by the WTO department of METI and the publication of the 
carries a more blatant title of Fukosei boeki hokokusho ("Unfair Trade Policies Report"), was intended to be a Japanese answer to the U.S. Trade Representative (USTR)'s "National Trade Estimates" (NTE) report. From the very beginning, the MITI report has been very critical of the aggressive unilateralism of the United States. From MITI's standpoint, while the NTE report simply catalogues complaints by the domestic industry, the MITI report was more objective, using the GATT rules as the benchmark for selecting objectionable trade policies and practices. ${ }^{18}$

During this period, Japan also actively participated in the Uruguay Round negotiations on dispute settlement. The primary goal for the Japanese delegation in the negotiations was to contain aggressive unilateralism of the United States, embodied in the frequent recourse to unilateral actions under Section 301 of the Trade Act of 1974. This objective was shared by many other delegations including the EC and India. As is well known, the result was Article 23 of the Dispute Settlement Understanding (DSU), which provides that "[w] hen Members seek the redress of a violation of obligations or other nullification or impairment of benefits under the covered agreements or an impediment to the attainment of any objective of the covered agreements, they shall have recourse to, and abide by, the rules and procedures of this Understanding.” As I note in Araki (2004), Japan would effectively use this provision to advance its interests once the WTO was established in the Section 301 (Automobiles) case (WT/DS6). As Ahn (2003, p. 13) observes:

"The very first complaint by Japan to the WTO ... indeed provided the Japanese government with profound confidence in the new system. Right after the WTO began its work in 1995, the United States threatened the unilateral retaliation on Japanese automobiles under Section 301. Instead of undertaking 'negotiations' as previously done, the Japanese government resorted to the WTO dispute settlement system by challenging the Section 301 measures. The United States finally withdrew the Section 301 threat and both parties notified the settlement of the dispute to the WTO on July 19, 1995. The outcome of this case forcefully illustrated the effectiveness and usefulness of the WTO dispute settlement system

\footnotetext{
report is authorized by METI bureaucracy, the report strongly reflects METI's view on multilateral trade policy.

18 See Pekkanen (2001, p. 711) and Iwasawa (2000, p. 478).
} 
as opposed to unilateralism."19

Japan's aggressive legalism in this historical context is still alive and well. Compared to the past practices in the 1950s through the mid-1980s, Japan has come a long way toward establishing its aggressive trade strategy in the multilateral trading system. Furthermore, Japan's aggressive legalism has had a public relations dimension as well. As noted above, METI's Fukosei Boeki Hokokusho has consistently emphasized the importance of a legal approach to trade disputes since 1992.

Aggressive legalism (although a softer expression like "trade policy based on international rules" is usually preferred) has been one of the publicly stated objectives of MITI/METI's policy. After the Section 301 (Automobiles) case was settled in Japan's favor, MITI triumphantly published a collection of position papers and texts of the final agreements. ${ }^{20}$ Clearly, MITI was trying to appeal to the public about the legitimacy and desirability of the new trade policy. Aggressive legalism has consequently been regarded as an important policy tool for managing the bilateral trade relationship between Japan and the United States.

But there is a problem in that there appears to be certain disconnect between the publicly stated goal and the actual performance by the Japanese government. If Japan was only moderately aggressive in the use of the WTO dispute settlement process as we have seen above, would it be possible to sustain the energy and devotion toward the multilateral dispute settlement process under the current environment of excessive enthusiasm toward regional trade

\footnotetext{
19 Another case brought by the EC in 1998 on Section 301 (WT/DS152) confirmed the supremacy of multilateralism over unilateralism. As a result, the U.S. government has learned that any Section 301 retaliation will be a target of countersuit at the WTO and has decided to route most of the Section 301 cases through the WTO. The United States is also committed to follow the rules of the DSU in the implementation/compliance phase of a dispute. See Iida (2004, p. 216).

20 MITI (1997). This unusual publication has a photo of then MITI minister Ryutaro Hashimoto and the USTR Mickey Kantor shaking hands on its cover.
} 
agreements? As early as 2001, Pekkanen already pointed to the potential danger of regionalism. Her conclusion was optimistic. She said (pp. 733-734):

"[T]his move toward regional pacts does not constitute an about-face with respect to Japan's keen interest in using the legal rules of the WTO to its advantage in trade disputes with the rest of the world. In fact, for the foreseeable future, it is a safe bet that Japan will continue to channel its dispute with partners like the US, EC, Canada, and perhaps even China in the near future, through the WTO system as much as possible. This is because, given the checkered and volatile bilateral past with the US, Japan's ability to be able to influence its partners' behavior depends heavily on sustaining the legal validity of its claims in the WTO system. Stripped of the procedural, substantive, and legitimate weight of the WTO rules, the Japanese government is more likely to flounder in confronting its major, as well as its minor, trade partners. For this reason, it should be recognized that Japan's emerging ambitions regarding regionalism stand in addition to, not instead of, its present emphasis on utilizing legal rules in a multilateral setting."

METI's Fukosei boeki hokokusho, noted above, is consistent with Pekkanen's prediction. It emphasizes the importance of both multilateral and regional trade rules, but much of the substantive discussion is devoted to utilizing the WTO rules. ${ }^{21}$ Table 1 itself suggests that the concerns about regionalism might be somewhat overblown. The NAFTA partners, Canada, Mexico, and the United States, have often had recourse to the WTO dispute settlement process. The same can be said of the MERCOSUR partners, Argentina and Brazil.

Nevertheless, the short-term impact of the excessive enthusiasm toward regionalism is already visible in the WTO department of the METI. Partly due to the stagnating negotiations in the Doha Development Agenda, many of the officers who used to work exclusively for the WTO

$21 \operatorname{METI}(2004$, pp. 347-361). 
department are now assigned an additional task of negotiating regional trade agreements, or are simply transferred to a division dealing with regional trade negotiations.

Now, what does METI say about its own diagnosis of the cause of Japan's not-so-aggressive legalism? Of course, it does not blame regionalism. It points to the inadequate level of public-private partnership in WTO litigation, and calls for further appreciation in the private sector of the importance of international trade rules. It also emphasizes the importance of making the government more accessible to companies that may have been disadvantaged by WTO-inconsistent actions by Japan's trading partners, without specifying how that goal can be achieved. Furthermore, pointing to the shortage of experts on WTO rules in Japan, METI would encourage the partnership between the private sector, academia and the government, and is expecting a greater role to be played by newly created graduate law schools. ${ }^{22}$

While these are valid points that merit serious consideration, there are other institutional reasons that might be inhibiting the aggressive use of WTO rules by the private sector in Japan. One reason is the lack of national complaint procedure. The METI report is conveniently silent on this issue. It is true that following the publication of the report, the Multilateral Trade System Department of METI has opened an “inquiry point” for compliance with WTO rules by Japan's trading partners on its Website, ${ }^{23}$ but it is an informal mechanism administered by one government agency, not a national complaint procedure.

\section{POSSIBILITY OF A FORMAL NATIONAL COMPLAINT MECHANISM}

For some time, Japanese academics have argued for the desirability of a national complaint mechanism. For instance, citing the examples of Section 301 of the U.S. Trade Act of 1974 and the EC's Trade Barriers Regulations, Iwasawa (2000, p. 485) argued:

\footnotetext{
22 METI (2004, pp. 355-358). For discussion of the new law school education, see Araki (2004).

23 www.meti.go.jp/policy/trade_policy/wto/compliance/sōdan.html
} 
"[N]ot only the United States but also the European Communities have national procedures allowing private persons to make petitions and to press the authorities to take an action in the WTO dispute settlement procedures. These procedures thus give private individuals indirect access to the WTO procedures. They contribute not only to the protection of private interests in international trade but also to the enforcement of the WTO Agreement through private surveillance. ... As national procedures have positive practical and theoretical effect, it is probably high time that one seriously consider the possibility of introducing such a procedure in Japan."

The private sector has been more vocal. Nippon Keidanren (Japanese Business Federation) called for the creation of a petition system for investigation regarding unfair trade practices of foreign nations on three separate occasions in May 1999, June 2001 and February $2004 .^{24}$ In the most recent call for action, Nippon Keidanren (2004) has stated:

"Japanese companies and associations are able to register complaints about unfair trade practices of foreign nations to the Ministry of Economy, Trade and Industry during the compilation of the annually published 'Report on the WTO Consistency of Trade Policies by Major Trading Partners. ${ }^{25}$ But there is no procedure for requesting initiation of an investigation with the aim of correcting the problems.

"As a result, at present, the only countermeasure that Japanese companies hurt by foreign trade practices can take is to make an appeal through an industry

\footnotetext{
24 The most recent call is available from the Nippon Keidanren website http://www.keidanren.or.jp/english/policy/ 2004/016.html, with links to the earlier calls.

25 This refers to Fukōsei bokei hokokusho. Needless to say, not all companies and associations have the privilege of being consulted by METI. Responses to METI's call for public comments on the report have not been very active.
} 
association or similar body to the government minister in charge. Although this method is not entirely without merit, in the sense that it affords government and the private sector a realistic means of response, it has been noted for its opacity and instability because it would seem to leave issues to the government's discretion.

"Moreover, the ministry in charge varies depending upon the affected sector. To illustrate, the Ministry of Economy, Trade and Industry would have to be addressed in matters of general industrial products; the Ministry of Agriculture, Forestry and Fisheries in matters of food or agricultural and marine products; the Ministry of Economy, Trade and Industry and the Ministry of Public Management, Home Affairs, Posts and Telecommunications in matters of telecommunications services; the Ministry of Land, Infrastructure and Transport in matters of transport, distribution, and construction services; the Ministry of Finance in matters of customs valuation; and the Ministry of Health, Labor and Welfare, and the Ministry of Justice in matters of immigration or employment, and so forth. Many Japanese companies also complain about the lack of a unified approach among the various ministries. Moreover, depending on the matter at issue, it may even be difficult to identify the minister in charge".

Accordingly, Nippon Keidanren is advocating the establishment of a national complaint mechanism similar to the EC's Trade Barriers Regulation and the U.S. Section 301, with the Cabinet Office as the recipient of the petitions.

How likely is this kind of proposal to be accepted by the government? In my judgment, it is extremely unlikely that government agencies would voluntarily give up their jurisdiction over trade matters. METI may like to see a certain controlled level of enhanced "public-private partnership" in WTO litigations, but certainly it would detest being controlled by private petitioners. 
To make the matter worse, the authority for ultimate action - WTO-authorized trade sanctions under Article 22 of the DSU - does not belong to a single agency in Japan. Article 6 of the Customs Tariff Law (on "retaliatory duty"), contains detailed provisions, which appear very cumbersome.

The Cabinet Order referred to in Article 6 (Cabinet Order No. 418 of 1994) specifies that the Minister of Finance has the power to determine the level of the retaliatory duty. Independently from this authority, the METI minister has the power to impose retaliatory measures in the form of quantitative restrictions under the relevant provisions of the Foreign Exchange and Foreign Trade Law. This is the Japanese equivalent of Section 301!

These baroque legal structures are protecting the prerogatives of customs and trade officials under the current rules. However, this is not an insurmountable barrier for institutional change. With a determined political leader, one day, the trade legislation of Japan could be completely rewritten and modernized. The fact that the recently amended Foreign Trade Law of China includes a chapter on a national procedure for foreign trade barriers investigation (without granting the right to petition to private parties, however $)^{26}$ may serve as a catalyst for this kind of change.

\section{CONCLUDING REMARKS}

In this paper, I have traced the evolution of Japan's aggressive legalism in the course of the development of the WTO dispute settlement mechanism. The drastic change in Japan's trade policy position in the early 1990s, i.e., the departure from the traditional non-legal spproach and the embracing of aggressive legalism, was a dramatic event both for Japan and its major trading

\footnotetext{
${ }^{26}$ The Foreign Trade Law of the People's Republic of China (adopted on 12 May 1994 at the Seventh Session of the Standing Committee of the Eighth National People's Congress and amended on 6 April 2004 at the Eighth Session of the Standing Committee of the Tenth National People's Congress), Articles 37 through 39. This is a codification of the earlier regulation on foreign trade barriers. See Ahn (2003, p. 35).
} 
partners. In hindsight, the Japan-U.S. automobile dispute in the summer of 1995 (WT/DS6) was probably the climax, symbolizing the new direction of Japan's trade policy. Thereafter, with the prolonged recession in Japan and the rise of economic powers in other parts of the world, bilateral disputes between Japan and the United States started to fade away from the major trade agenda.

Thus, while METI consistently emphasized the importance of rules-based trade policy, Japan's activity in the WTO dispute settlement system remained relatively moderate, casting doubt on the validity of the original assumption of Japan's aggressive legalism. However, Japan is far more aggressive than in the past in utilizing the rules of the GATT/WTO to advance its national interests. It will never revert to the earlier practice of bilateralism and gray area measures.

It is true that Japan came close to openly demanding gray area measures from China in the mushroom-onion-tatami dispute of $2001,{ }^{27}$ but that was an isolated incident with a country that was not yet a member of the WTO. If a similar dispute arises between Japan and China in the future, both countries as responsible WTO members will have to act more within the formal legal procedures. Indeed, as Pekkanen (2001, p. 734) notes, aggressive legalism is a double-edged sword. If Japan asks its trading partners to play by the rules, then it must accept the principle of fair play. Thus, Japan will continue to uphold the integrity of the WTO dispute settlement mechanism, which is the "central element in providing security and predictability in the multilateral trading system" (Article 3.2, DSU). "How aggressively?" is a question that remains to be answered.

\section{REFERENCES}

Ahn, D. (2003), 'WTO Dispute Settlements in East Asia,' NBER Working Paper 10178.

27 See Nakagawa (2003). 
Araki, I. (2004), 'Beyond Aggressive Legalism: Japan and the GATT/WTO Dispute,' in M. Matsushita and D. Ahn (eds.), WTO and East Asia: New Perspectives (Cameron).

Davey, W. J. (2002), 'Japan, WTO Dispute Settlement and the Millennium Round' in R. M. Stern (ed.), Issues and Options for U.S.-Japan Trade Policies (University of Michigan Press).

Hatakeyama, N. (1996), Tsusho kosho - kokueki o meguru dorama ('Trade Negotiations: A Drama Involving National Interest'), Nihon Keizai Shinbunsha (Nikkei).

Iida, K. (2004), 'Is WTO Dispute Settlement Effective?' Global Governance 10, 207-25.

Iwasawa, Y. (2000), 'WTO Dispute Settlement and Japan' in M. Bronckers and R. Quick (eds.), New Directions in International Economic Law (Kluwer Law International).

Leitner, K. and S. Lester (2004), 'WTO Dispute Settlement 1995-2003: A Statistical Analysis,' Journal of International Economic Law 7, 169-181.

Ministry of Economy, Trade and Industry (2004), Fukōsei boeki hokokusho ('Unfair Trade Policies Report').

Ministry of International Trade and Industry, Americas Division (1997), Nichibei jidosha kosho no kiseki ('The History of the Japan-U.S. Automobile Negotiations').

Nakagawa, J. (2003) 'Lessons from the Japan-China 'Welsh Onion' War,' Journal of World Trade 36, 1019-36.

Pekkanen, S. (2001), 'Aggressive Legalism: The Rules of the WTO and Japan's Emerging Trade Strategy,' The World Economy 24, 707-37.

World Trade Organization (2004), Update of WTO Dispute Settlement Cases (WT/DS/OV21). 
TABLE 1

State-of-Play of WTO Dispute Settlement, June 2004

\begin{tabular}{|c|c|c|c|c|c|c|c|c|c|c|c|c|c|c|}
\hline Cemplainant & $\begin{array}{l}\text { United } \\
\text { States }\end{array}$ & $\mathrm{EC}$ & Canada & Brazil & India & Mexico & Japan & Korea & Thailand & Argentina & Chile & Australia & Others & $\begin{array}{l}\text { Total number } \\
\text { of responses }\end{array}$ \\
\hline United States & - & 26 & 13 & 8 & 6 & 5 & 7 & 7 & 2 & 2 & 2 & 2 & 15 & 95 \\
\hline $\mathrm{EC}$ & 29 & - & 7 & 6 & 4 & 3 & 0 & 3 & 4 & 2 & 1 & 2 & 13 & 74 \\
\hline Canada & 4 & 3 & - & 3 & 0 & 0 & 1 & 0 & 0 & 0 & 0 & 0 & 1 & 12 \\
\hline Brazil & 4 & 3 & 1 & - & 1 & 0 & 1 & 0 & 0 & 0 & 0 & 0 & 2 & 12 \\
\hline India & 3 & 8 & 1 & 0 & - & 0 & 0 & 0 & 0 & 0 & 0 & 1 & 3 & 16 \\
\hline Mexico & 6 & 1 & 0 & 1 & 0 & - & 0 & 0 & 0 & 0 & 1 & 0 & 2 & 11 \\
\hline Japan & 6 & 6 & 1 & 0 & 0 & 0 & - & 0 & 0 & 0 & 0 & 0 & 0 & 13 \\
\hline Korea & 6 & 4 & 1 & 0 & 0 & 0 & 0 & - & 0 & 0 & 0 & 1 & 1 & 13 \\
\hline Thailand & 0 & 0 & 0 & 0 & 0 & 0 & 0 & 0 & - & 0 & 0 & 0 & 1 & 1 \\
\hline Argentina & 4 & 6 & 0 & 2 & 1 & 0 & 0 & 0 & 0 & - & 1 & 0 & 1 & 15 \\
\hline Chile & 1 & 3 & 0 & 0 & 0 & 0 & 0 & 0 & 0 & 3 & - & 0 & 3 & 10 \\
\hline Australia & 4 & 1 & 1 & 0 & 0 & 0 & 0 & 0 & 0 & 0 & 0 & - & 3 & 9 \\
\hline Others & 11 & 2 & 1 & 2 & 3 & 5 & 2 & 1 & 4 & 2 & 4 & 1 & & 59 \\
\hline $\begin{array}{l}\text { Total number } \\
\text { of complaints }\end{array}$ & 78 & 63 & 26 & 22 & 15 & 13 & 11 & 11 & 10 & 9 & 9 & 7 & 66 & 340 \\
\hline
\end{tabular}

Note: This table is compiled from the WTO Secretariat's "Update of WTO Dispute Settlement Cases" (WT/DS/OV21), dated 30 June 2004. Total number of cases (340) exceeds the number of cases identified by the WTO Secretariat (312 as of 16 June 2004) because joint complaints in a single panel case (e.g., the Bananas case, WT/DS27) are counted separately (as five different complaints by the United States, Ecuador, Guatemala, Honduras and Mexico in this case). 
TABLE 2

WTO Cases Initiated by Japan

Filing Date Case Title

May $1995 \quad$ United States - Imposition of Import Duties on Automobiles from Japan under Sections 301 and 304 of the Trade Act of 1974 (WT/DS6)

Jul. 1996 Brazil - Certain Automotive Investment Measures (WT/DS51)

Oct. 1996 Indonesia - Certain Measures Affecting the Automobile Industry (WT/DS55)*

Nov. 1996 Indonesia - Certain Measures Affecting the Automobile Industry (WT/DS64)*

Jul. 1997 United States - Measure Affecting Government Procurement (WT/DS95)*

Jul. 1998 Canada - Certain Measures Affecting the Automobile Industry (WT/DS139)*

Feb. 1999 United States - Anti-Dumping Act of 1916 (WT/DS162)*

Nov. $1999 \quad$ United States - Anti-Dumping Measures on Certain Hot-Rolled Steel Products from Japan (WT/DS184)*

Dec. $2000 \quad$ United States - Continued Dumping and Subsidy Offset Act of 2000 (WT/DS217)*

Jan. 2002 United States - Sunset Review of Anti-Dumping Duties on Corrosion-Resistant Carbon Steel Flat Products from Japan (WT/DS244)*

Mar. $2002 \quad$ United States - Definitive Safeguard Measures on Imports of Certain Steel Products (WT/DS249)*

Note: 11 cases on 10 distinct matters; panels were established regarding the eight cases marked with asterisks. 
TABLE 3

WTO Cases Brought Against Japan

\begin{tabular}{|c|c|c|}
\hline Filing Date & Case Title & Complainant \\
\hline Jun. 1995 & Japan - Taxes on Alcoholic Beverages (WT/DS8) * & $\mathrm{EC}$ \\
\hline Jul. 1995 & Japan - Taxes on Alcoholic Beverages (WT/DS10)* & Canada \\
\hline Jul. 1995 & Japan - Taxes on Alcoholic Beverages (WT/DS11)* & United States \\
\hline Aug. 1995 & Japan - Measures Affecting the Purchase of Telecommunications Equipment (WT/DS15) & $\mathrm{EC}$ \\
\hline Feb. 1996 & Japan - Measures Concerning Sound Recordings (WT/DS28) & United States \\
\hline May 1996 & Japan - Measures Concerning Sound Recordings (WT/DS42) & $\mathrm{EC}$ \\
\hline Jun. 1996 & Japan - Measures Affecting Consumer Photographic Film and Paper (WT/DS44)* & United States \\
\hline Jun. 1996 & Japan - Measures Affecting Distribution Services （WT/DS45) & United States \\
\hline Jan. 1997 & Japan - Measures Affecting Imports of Pork (WT/DS66) & $\mathrm{EC}$ \\
\hline Mar. 1997 & Japan - Procurement of a Navigation Satellite (WT/DS73) & $\mathrm{EC}$ \\
\hline Apr. 1997 & Japan - Measures Affecting Agricultural Products (WT/DS76)* & United States \\
\hline Oct. 1998 & Japan - Tariff Quotas and Subsidies Affecting Leather (WT/DS147) & $\mathrm{EC}$ \\
\hline Mar. 2002 & Japan - Measures Affecting the Importation of Apples (WT/DS245)* & United States \\
\hline
\end{tabular}

Note: 13 cases on 10 distinct matters; panels were established regarding the four cases marked with asterisks. 